the various transactions in selling land for this purpose. This completes the list of manuscript material which relates to canal and railroad construction.

\title{
Contributions to Source Material for Business History
}

THERE is one type of source material for business history to which members of the Society could and should make valuable contributions. This is in the recording of the significant facts concerning the development of their own business concerns. After a man has spent the best years of his life and much of his talent and energy in administering a business enterprise, it would be of great value if he could sit down and, as clearly as possible, describe all sides of every problem which led to the formulation of important decisions, along with the results of the policies based on those decisions. By collecting such impressions over a period of years, there could be brought together a mass of information which would be important to the study of business history.

Already, two such pieces have come to the Society: Woolen Manufacturing in Amesbury, $1821-1852$ by Joshua Aubin and The Collins Company, I826-1867 by Samuel Watkinson Collins. The latter, a history of a company manufacturing axes, is particularly interesting, at this time, because of the great amount of space devoted to the discussion of various depression periods. The year 1833 brought not only financial problems, but labor difficulties as well and forms one of the most interesting portions of the record:

This was an eventful year. The panic in consequence of the Asiatic Cholera disarranged business and checked sale of our goods. Workmen were dissatisfied with our attempts to organize the business more economically and we found it impossible to make sales and collections fast enough to meet our expenses, especially at the Hartford. Bank, and was disposed to curtail the loans made to us on accomodation paper. D. C. Collins was a Director in the Phoenix Bank but our loans there were not large.

As much had been said about our stringent and illiberal contracts with workmen in the first years of the business, the "temperance principles" and rigid rates. I will transcribe here a copy of a correspondence with 
them which took place in April of this year, the first time there ever was a combination among them and a refusal to work. At that time we employed none but Americans and we had been able to select our men, consequently they were a pattern of order and sobriety. The objectionable feature was that in retaining a portion of wages and paying at long intervals, then bringing them as apprentices learning a trade, we became largely indebted to them.

\section{S. W. Collins to the workmen in Collinsville.}

"I have received through your highly respectable committee, a very respectful remonstrance against our alteration of piece prices, and I am particularly pleased with the candid manly course which you have pursued at this crisis. It is worthy of yourselves and the high character you have always sustained as a community. It is creditable to you as American citizens and speaks well for Universal Sufferage and the prospects of our Republic. I am personally peculiarly gratified as it confirms me in the policy I have always adopted and advocated, viz: to employ no foreigners; none but Americans, believing them to be not only more ingenious and industrious than foreigners, but more enlightened and consequently more rational and reasonable. The character which this Village has sustained has demonstrated this theory to be correct, and I am proud of the fact that we are mentioned far and near as a sample of what manufacturing communities may be in this country. Thus it has been in times past and it only needed a fluctuation in price of wages (which is sure to come sooner or later in all kinds of business owing to over-production and a variety of causes) to test the experiment fully. That time has arrived and what is the result? Instead of such disorderly and disgraceful conduct as we hear of in manufacturing communities in other countries on similar occasions and which had prejudiced some against manufacturing in this country, and to question the policy and expediency of allowing them the rights of freemen at the polls, we find them here assembling quietly by hundreds. Not at a Tavern to heat their blood and warp their judgment with grog, but in the cool open air in front of a temperance store where pen and ink and paper can be procured and business conducted in a truly Republican town-meeting style. That the assembly was composed of cool, dispassionate, reasonable men I want no better proof than $I$ have in the appearance and character of the men who waited on me this morning as your committee. They would do a credit to any community and I am proud to claim them as my fellow citizens, as such permit me to address you all, and I am glad to have this opportunity to rectify some wrong impressions which $I$ am informed exist (though $I$ cannot believe it is the case to any extent) viz: that I am myself an avaricious, hard-hearted man, selfish and unreasonable, without patriotism and public spirit and caring for nothing but my own selfish gratifications. I trust that many in this community know me better, 
but perhaps it is not strange that some who have not been here long and with whom I have not had much personal intercourse should entertain such ideas and suppose that I wish to oppress them, whereas nothing can be further from the thoughts and intent of my heart. If there is one truth more fully impressed on my mind than another it is that "the rich and the poor will meet together. The Lord is the Maker of them all."

I have been less inclined to mingle in religious or political strife that I may more impartially discriminate and deal more justly with the members of this community, but I have feelings as well as other men, and I would rather a man would suspect my pecuniary credit than my patriotism or generosity. If there is a favorite object or pursuit with me it is the welfare and happiness of the inhabitants of this village, and that can only be prompted effectually and permanently by such prudent and judicious management of our business as will enable us to meet all our engagements.

I have addressed you personally instead of using the name of our Company, that I might address you more familiarly for I consider my personal reputation involved. I am not aware that I have ever forfeited my character for veracity and I expect that you will believe me when I say that we cannot afford to pay such prices as we have paid. Although we keep up the retail prices of our axes we have been obliged to make heavy discounts on our large sales. We had hoped the business would be such that we could afford to pay you high wages.

You will readily believe me when you take into consideration the course we have pursued in times past. When we first commenced business, wages were very low (much lower than we now offer to pay) and many of you contracted with us for five years at those low rates. Afterwards when wages advanced instead of exacting labor of you at those low rates we increased your wages giving you work by the piece at prices that enabled you to make double the money you contracted to work for, and we released many of you from the last two years of your contract, and when we found that the axes were costing us nearly as much as we got for them we raised the price of the axes instead of reducing wages, and so paid you liberally, and now we have made no more reduction than we consider absolutely necessary. We have not decided on this change hastily but after much delay and mature consideration. We are truly sorry that we cannot do better by you. The only proof that we can give you now of our disposition to be liberal with you and take no advantage of circumstances is by assuring you that as your time of settlement comes around every man shall have an opportunity to pocket his contract and go free unless he prefers to stay.

If you think you can commence work under the new tariff with better courage after a holiday and a game of ball you can take next Monday and enjoy yourselves.

Respectfully, Your friend Sam'l. W. Collins." 
This reply was received from the workmen.

"The Committee to whom your communication was addressed respecting reduction of wages are directed by the unanimous vote of the meeting before whom it was read to express to you their entire satisfaction with the views therein contained, and their resolution to go on cheerfully in the discharge of their duties. While they do this the Committe in the name of the meeting would assure you that they are happy to find the course which they have pursued has met with your approbation, and has been treated with such frankness and good feeling. We have no doubt of the correctness of the statements in your communication and our entire confidence in our employer will not allow the supposition that he could wish anything unreasonable.

In the welfare of our village and in the prosperity of the manufacturing interest of our Country, we, as residents, here and as American citizens, feel a deep interest and hope to do all in our power to promote our common welfare.

With respect and esteem, Yours, Signed by Charles Blair, Henry D. Rogers and others."

It was a critical time with us, as we could not sustain our prices of axes we were obliged to reduce the cost.

The contracts with the workmen rather complicated matters, and the workmen combining to quit made it look rather squally, especially as there was a large amount due to them.

As there was but a few axe makers in the country we was obliged to take common blacksmiths and learn them to make axes, as they would utterly spoil some of the iron and steel and make a large quantity of poor work that could not receive our stamp and must be sold cheap, we bound them to work for several years paying but once a year and then retaining a part of their wages until an equal amount was earned on the following year. We had no difficulty in finding men to sign the contracts. Usually $\$ 14.00$ and board the ist year, $\$ 16.00$ the second year, $\$ 18.00$ third, $\$ 20.00$ the fourth year, $\$ 26.00$ the fifth year, though some of the contracts were only for three years.

The trouble with them arose after they had got to be good workmen and could get high wages elsewhere. To obviate this we gave piece work by which all who could make good work got good wages, but we lost money on the inferior work done by new hands. It was only our rigid inspection and putting our name onto none but good work that enabled the establishment to survive all the vicissitudes encountered.

In the month of September [1 833] the Hartford Bank having fallen into the hands of a new set of Directors, turning out of the Presidency our friend General Terry and electing Gov. Trumbull, we were notified to pay up which we could not do in the time specified, and concluded to 
suspend payment and assign our property to Trustees for the benefit of our creditors. The property being previously under heavy mortgages to James H. Wells (father of William and John) for advances in money and indorsements. Mr. Wells took possession by consent of the Trustees and run the Works about a year, working up stocks on hand and selling axes until he got his pay in December 1834 when the Trustees came in possession, they sold it at auction with what stock and other personal property remained, for the benefit of our creditors, they having obtained an Act of Incorporation (or we had got it for them, the Trustees being named as the Corporation) took pay in stock for their claims against us and thus released us from our debts.

It is natural that much of the description throughout the account constitutes a more or less tedious chronology of events, but depression periods always called forth some interesting observations. Of 1837 he writes:

In January not able to do much work for want of water.

D. C. Collins resigned as Treasurer on account of his health and Alfred Smith, Esq., President of Conn. River Bank, was appointed Treasurer.

The panic which had been increasing several months culminated in May by all the Banks in the U. S. stopping specie payment (including the U. S. Bank).

It now became painfully evident that we had made a great mistake the previous year in paying such large dividends to Stockholders as we now needed the funds to sustain the Concern.

We showed a prosperous business in the semi-annual meeting in April, but instead of a dividend, created and sold in May, at par, \$50,000. new stock to raise money. (In 1838 made stock dividend of $\$ 50,000$. This last creation of stock raised the amount to $\$ 300,000$. which was the limit assigned by our Charter.)

The financial embarrassments of the Country and general prostration of business found us with all our sales spread, having large stocks of raw material on hand and with large contracts for iron to be delivered. We had notes to pay and not much to pay with. Our sales were small and we had very little cash capital, instead of providing capital as we should have done in $183^{6}$ when money was easy and our profits large.

The large Stockholders and Directors residing in New York and Philadelphia pursued a different policy. They made large dividends and sold out when the stock brought high prices. The Concern was now in a critical situation and the Treasurer, Mr. Smith, called the Directors together frequently. At one time they had daily meetings adjourning from day to day, debating financial expedients and trying to negotiate with some of the Banks for aid. 